\title{
The Effectiveness of Blended Learning Using the Flipped Classroom and Hybrid Learning Models in the Chuukuuu Bunpou
}

\author{
Rita Agustina Karnawati ${ }^{1, *}$ Aulia Istianingrum ${ }^{2}$
}

\author{
${ }^{1}$ Muhammadiyah Prof. DR. HAMKA University \\ ${ }^{2}$ Muhammadiyah Prof. DR. HAMKA University \\ *Email: Rita_Japanese@yahoo.com
}

\begin{abstract}
This research aims to analyse the effectiveness and the differences in the effectiveness techniques of hybrid learning and flipped classroom from the blended learning method in the chuukyuu bunpou. for the fourth semester students of Japanese Language Education, Muhammadiyah Prof. DR. HAMKA University 2019-2020. The method used in this research is true experiment with pre-test post-test two group design. The sample consisted of 19 respondents in class experiment 1 which applied hybrid learning and 17 respondents in class experiment 2 which applied flipped classroom. T test results between hybrid learning and flipped classroom are gained Sig. ( 2 tailed) point 0.207 , greater than the significance level, 0.05 . It concluded that there is no significant difference between learning outcomes using hybrid learning and flipped classroom. From the normalized gain test results in both classes, the normalized gain score for hybrid learning is 0.49 and the normalized gain score for flipped classroom is 0.34 so that both have moderate effectiveness. The percentage of normalized gain for hybrid learning is $49.50 \%$ while flipped classroom is $33.86 \%$. Conclusion is the effectiveness of blended learning by hybrid learning is greater than blended learning by flipped classroom in the chuukyuu bunpou.
\end{abstract}

Keywords: Blended Learning, Method, Flipped Classroom, Hybrid Learning

\section{INTRODUCTION}

In the era of 21 st century, learning skills consisting of critical thinking, collaboration, creativity and communication. Learning outcomes that are expected to be owned by learners in life and careers are: 1) Flexibility and adaptability, 2) Initiative and selfdirected, 3) Social skills and cross-cultural sensitivity, 4) Productivity and Accountability, 5) Leadership and responsibility. (Arifin, Syamsul. 2020). Japanese language learning has many levels, especially in learning grammar. With a beginner level called shokyuu bunpou, and an intermediate level called chuukyuu bunpou. This grammar learning includes mastery of vocabulary, sentence structure, particles and verb changes. In order to be able to master or arrange sentences correctly according to their learning level, learners are required to be able to master all grammar at the level being studied. In bunpou learning, difficulty memorizing grammar is often experienced by Japanese learners. Apart from the many sentence patterns, it is often also found that the same grammar has different meanings. This difficulty will affect other skills such as writing, speaking, listening and reading. So that we need a method that suits these needs. The learning method that is still used in bunpou learning is face-to-face learning. Face-to-face learning has many advantages, especially direct meetings with instructors or instructors without going through the media, making it easier for two-way communication, but currently technological advances and the use of media such as social media are increasing sharply, providing new challenges for instructors who always use face-to-face learning to try to use technology in learning. One alternative to learning is blended learning, in which learning in addition to using face to face directly, learning is also developed through social networks such as the internet. Blended learning can facilitate learners to be able to learn more freely anytime and anywhere outside of faceto-face study hours, besides that it can also provide learning access to learning resources more freely and varied. learners can discuss and exchange learning 
experiences anytime and anywhere, both with fellow learners and with instructors.

\section{OVERVIEW OF BLENDED LEARNING}

Bryan and Volchenkova stated that blended learning is an effective learning method using technology, besides being a learning solution that has a more effective learning experience, increases access and flexibility and reduces learning costs. Learning with this method is not only a bridge between the distance between the learner and the instructor but also a bridge of time (the use of recordings, whether sound recordings, pictures or videos) and provides opportunities for learners to manage their learning time and method. (Bryan \& Volchenkova, 2016). Blended learning applies two methods, namely asynchronous and synchronous, both of which are interrelated in their application.

\subsection{Asynchronous and Synchronous Learning Method}

The definition of flipped learning is, learning is divided into two with four spaces, namely asynchronous outside the classroom and synchronous in the classroom. When the independent asynchronous process, the lecturer conducts activities of seeing, reading, listening, paying attention to learning objects in various types and formats of digital media and preparing material, then the collaborative asynchronous lecturer sends material, students criticize, discuss, evaluate, compare, research and others that are mediated by collaborative technologies, such as LMS platforms such as google classroom, WAG, etc., this is where the process is reversed where students are actively learning and lecturers act as facilitators. After that, entering the virtual synchronous stage, lecturers and students conduct discussions, dialogues, and question and answer demonstrations with lecturers through synchronous technologies such as Zoom, Webex etc. The final stage is direct synchronization, namely face to face with discussions, questions and answers, demonstrations, simulations, practices, case studies, problem solving etc. with lecturers in class. Online learning is very effective in learning Japanese sentences and communication (Cuaca Dharma et al., 2017). The advantage of learning using online webinar media, such as Skype and Zoom, is the capability to enable participants to interact in writing and pronunciation and to go through presentations to share multiple views. Synchronous and Asynchronous learning methods are widely used methods to interact in the learning environment, where the advantage lies in not always having students meet at the same place and time, but being able to share knowledge wherever they are.

\subsubsection{Synchronous Learning Method}

This method is when students and instructors exchange information and interact simultaneously in an online learning community using a predetermined time using learning technologies including internet conferencing, satellites, video teleconferencing and chat. The Advantages of this method is students can ask direct questions that can be answered by the tutor or the facilitator; activeness in a lesson will look like in a faceto-face room; In the classroom, students and tutors can communicate better, and the awkwardness of students in the normal classroom will not be seen. Meanwhile the deficiencies of this method is must use high speed internet access in real time so that participants cannot access at another time, unless scheduled; and do not give participants long time to think.

\subsubsection{Asynchronous Learning Method}

Whereas for asynchronous learning is learning freely not bound by time, where students can interact with special materials and with each other at the time they choose. One of the things that can be done is when students post their thoughts, on a day that is determined by themselves and other students provide comments on posts such as discussion forums. The advantages is very high quality dialogue can be achieved using the discussion structure and gives participants more time to think about what to post; students who take part in the lesson can choose any time which is the right time; and students can freely study whenever they have time. And the deficiencies is there is a lack of communication in language or writing that is not readily accepted by readers; and requires an internet connection.

\subsection{Overview of Blended Learning by Flipped Classroom}

Blended learning can be done using flipped classroom. Flipped classroom itself is a learning model whose application is reversed from the application of conventional learning which is one of the options for implementing learning using blended learning.

\subsubsection{The definition of Blended Learning by Flipped Classroom}

According to Rindaningsih, learning with a flipped classroom is learning where in getting learning material, students are responsible for obtaining it independently through online. Flipped classroom can also increase learning motivation and maximize learning success (Rindaningsih, 2018). Learning with this method is by reversing traditional teaching procedures and using online teaching videos to deliver teaching content. Instructional videos will give students the ability to take responsibility for their learning. (Pavanelli, 2018). 
Flipped classrooms are implemented in the form of active learning, by connecting with students, using hybrid courses (using technology by applying learning elements as is done in a conventional way) and podcasting. In a flipped classroom, instructors make learning videos, screencasts or podcasts and so on that will be taught to students outside of academic activities in the classroom, and make the best use of class time to connect with students through collaborative activities facilitated by the instructor (Milman, 2012). Learning using flipped classrooms has the advantage of promoting team learning abilities, and a learning model that is more future-oriented (Sojayapan \& Khlaisang, 2018).

\subsubsection{Blended Learning by Flipped Classroom Practices}

The definition of flipped learning is learning divided into two with four spaces, namely asynchronous outside the classroom and synchronous in the classroom. When the independent Asynchronous process, the lecturer conducts activities of seeing, reading, listening, paying attention to learning objects in various types and formats of digital media and preparing material, then the collaborative asynchronous lecturer sends material, students criticize, discuss, evaluate, compare, research and others that are mediated by collaborative technology, such as google classroom, WAG etc. In this learning model, active learners find and analyse learning material received before the actual learning is held. In fact, learning is a virtual synchronous stage, instructors and learners carry out discussions, dialogues, question and answer demonstrations with lecturers through synchronous technology such as Zoom or during a live meeting. in the classroom. The final stage is direct synchronization, namely face to face with discussions, questions and answers, demonstrations, simulations, practices, case studies, problem solving, etc. with lecturers in class (Narayana, 2016). The use of technology that is currently developing, which is of course the main desire to be able to better convey knowledge to educators and be able to provide a better scientific influence, Synchronous and Asynchronous learning methods are widely used methods, to make interactions in the learning environment, where the advantage lies in not always the students meeting at the same place and time, but being able to share knowledge wherever they are. (Teo, 2019). Online learning. This learning is carried out using computer media, mixed classes to assign several students, understanding statistical concepts followed by synchronous and asynchronous online, and video-based discussions. To determine the assessment of learners, instructors can use the meter application or online quizzes to get real-time grades or learning outcomes that can be accessed anywhere.

\subsection{Overview of Hybrid Learning}

Hybrid learning, is the application of learning that is very similar to face-to-face learning but by using learning media through SNS (Social Network Service), as well as other learning media such as google classrooms and so on, the application of which is blended learning in general.

\subsubsection{The Definition of Hybrid Learning}

The application of hybrid learning is virtual learning. Learning with this model allows students to watch and listen to the teacher at home and display their interactions and knowledge in hybrid learning that has been synchronized in the same way as learning in real classrooms (Ismail \& Abdulla, 2019). Hybrid learning allows flexible learning to be carried out collaboratively by learners and instructors. Hybrid learning can be tailored to the needs of learners and instructors such as speed, time and space. In contrast to traditional learning, hybrid learning can offer various kinds of opportunities for individuals who are limited by time and space. Hybrid learning has also been found to be conceptually effective and can be applied in various forms of collaborative learning approaches across disciplines (Alnajdi, 2014).

\subsubsection{Hybrid Learning Practices}

The application of hybrid learning is the same as the application of blended learning in general. Where this learning strategy requires learners to be involved in conventional and virtual learning classes. The application of learning is virtually the same as the application in conventional classes where learners will receive material, analyse and discuss material during learning hours. Learning in hybrid or virtual classes, namely learning by reading learning content in the form of pdf files, watching videos, and working on questions in the form of online program code (such as kahoot, mentimeter, etc.) to understand logic and analyse problems. When the material in one learning session has been studied, learners use the meter, kahoot or online quiz application as an assessment, so that learners can easily monitor the results of the learning that has been done. For face-to-face classes, the learning process is carried out in a real class, the lecturer teaches theory, and after completing studying the material in one session, students work on test questions using the mentimeter application (online quiz) (Jusuf, Ibrahim, \& Suparman, 2019).

\section{METHODS}

The form of the research used was a pure experiment and a two-group pre-test post-test design through an associative quantitative approach which investigated the 
relationship between 2 or more variables and simple correlation techniques to find the relationship between variables (X1 to $\mathrm{Y}$ and $\mathrm{X} 2$ to $\mathrm{Y}$ ). Then determine which one is more effective between $\mathrm{X} 1$ and $\mathrm{X} 2$ and its effect on $\mathrm{Y}$ by using two experimental classes. Sample in the form of 4th semester students of Japanese Language Education UHAMKA, 4A class with 19 respondents will be treated with blended learning by hybrid learning (X1) and 4B class with 17 respondents will be treated with blended learning by flipped classroom (X2). Learning flipped classroom with two different treatments is used social media in the form of a whatsapp group. This research was conducted by meeting four times with the experimental class, as well as testing the pre-test and post-test once each. Data collection with the results of pre-test and post-test assessments and analysed with data testing carried out on SPSS Statistic 25 starting from the normality test, $\mathrm{t}$ test, homogeneity test, and normalized gain test to determine the amount or percentage of increase or decrease in learning outcomes (effectiveness).

\section{RESULT AND DISCUSSION}

\subsection{Overview of Hybrid Learning}

The independent variable data is hybrid learning (X1) and flipped classroom (X2) and the dependent variable is chuukyuu bunpou (Y). This descriptive test uses SPSS Statistics 25 and functions to determine the minimum, maximum, range, and average (mean) value of the learning outcomes of each experimental class to determine whether the value of learning outcomes has increased, decreased or remained constant.

Table 1. Descriptive analysis 4A class

\begin{tabular}{|c|c|c|c|c|c|c|c|}
\hline \multicolumn{8}{|c|}{ Descriptive Statistics } \\
\hline & $\mathrm{N}$ & Range & Minimum & Maximum & Sum & Mean & $\begin{array}{l}\text { Std. } \\
\text { Deviation }\end{array}$ \\
\hline Nilai Pretest & 19 & 66 & 28 & 94 & 1141 & 60.05 & 16.952 \\
\hline Nilai Post Test & 19 & 49 & 51 & 100 & 1496 & 78.74 & 16.888 \\
\hline $\begin{array}{ll}\text { Valid } \\
\text { (listwise) }\end{array} \quad \mathrm{N}$ & 19 & & & & & & \\
\hline
\end{tabular}

In table 1 , the average of the pre-test score is 60.05 while the post-test score is 78.74 in $4 \mathrm{~A}$ class. The results of the descriptive statistics for $4 \mathrm{~A}$ class showed an increase in value after hybrid learning was applied.

Table 2. Descriptive analysis 4B class.

\begin{tabular}{|c|c|c|c|c|c|c|c|}
\hline \multicolumn{8}{|c|}{ Descriptive Statistics } \\
\hline & $\mathrm{N}$ & Range & Minimum & Maximum & Sum & Mean & $\begin{array}{l}\text { Std. } \\
\text { Deviation }\end{array}$ \\
\hline Nilai Pretest & 17 & 58 & 31 & 89 & 1168 & 68.71 & 18.020 \\
\hline Nilai Posttest & 17 & 35 & 63 & 98 & 1395 & 82.06 & 10.721 \\
\hline $\begin{array}{ll}\text { Valid } & \mathrm{N} \\
\text { (listwise) } & \end{array}$ & 17 & & & & & & \\
\hline
\end{tabular}

In table 2, the average of pre-test score is 68.71 while the post-test score is 82.06 in $4 \mathrm{~B}$ class. The results of descriptive statistics for $4 \mathrm{~A}$ class show an increase after the implementation of flipped classroom. After a descriptive analysis was carried out, based on the mean value of pre-test and post-test for $4 \mathrm{~A}$ class and $4 \mathrm{~B}$ class, it increased after the implementation of hybrid learning and flipped classroom using blended learning.

\subsection{Testing data requirements}

\subsubsection{Normality Test}

To determine whether the data is parametric or nonparametric and to determine the type of test used in the next test, the normality test is used. According to Sundayana, in the normality test, data with a sig. higher than the significance level $(0.01$ or 0.05$)$ means that it is normally distributed so that the data is parametric. The $t$ test on this data was 36 pieces with a significance level of 0.05 , so Shapiro Wilk was used.

Table 3. Normality Test.

Tests of Normality

\begin{tabular}{lccc}
\hline & \multicolumn{3}{c}{ Shapiro-Wilk } \\
& \multicolumn{1}{c}{ Statistic } & df & \multicolumn{2}{c}{ Sig. } \\
\hline nilai_pretest_4A &, 958 & 19 &, 537 \\
nilai_postest_4A &, 910 & 19 &, 074 \\
nilai_pretest_4B &, 912 & 17 &, 106 \\
nilai_postest_4B &, 954 & 17 &, 527 \\
\hline
\end{tabular}

Based on table 3, the Sig. 2 tailed data in 4A class and $4 \mathrm{~B}$ is greater than the significance level in this study, namely 0.05 , so the data in both classes are normally distributed. So, it will continue with parametric testing.

\subsubsection{T-Test}

This research uses independent sample t-test. The ttest can be used on parametric data. From the normality and homogeneity tests in classes $4 \mathrm{~A}$ and $4 \mathrm{~B}$, the two data are said to be normal and homogeneous so that the t-test can be done on both of them to determine whether the initial and final abilities of each class have significant differences.

Table 5. T test for Pre-test and Post-test 4A class.

\begin{tabular}{|c|c|c|c|c|c|c|c|c|c|c|}
\hline \multicolumn{11}{|c|}{ Independent Samples test } \\
\hline & & & & & & Sig. (2- & Mean & Std. Error & $\begin{array}{l}95 \% \text { Con } \\
\text { Interval of }\end{array}$ & $\begin{array}{l}\text { İdence } \\
\text { ifference }\end{array}$ \\
\hline & & $\mathrm{F}$ & Sig. & $t$ & df & tailed) & Differences & Differences & Lower & Upper \\
\hline hasil & $\begin{array}{l}\text { Equal variance } \\
\text { assumed }\end{array}$ &, 398 &, 532 & 4,036 & 36 & ,000 & $-20,474$ & 5,072 & $-30,761$ & $-10,186$ \\
\hline & $\begin{array}{l}\text { Equal } \\
\text { variances not } \\
\text { assumed }\end{array}$ & & & 4,036 & 4,922 & ,000 & $-20,474$ & 5,072 & $-30,772$ & $-10,175$ \\
\hline
\end{tabular}

If the Sig. (2 tailed) is lower than the significance level of 0.05 , so between the pre-test and post-test values in $4 \mathrm{~A}$ class there is a 
significant difference in value. In table 6, the Sig. 2 Tailed is 0.000 , so there is a significant difference between the pre-test and post-test scores in $4 \mathrm{~A}$ class. Then proceed with the t-test for the pre-test and post-test scores of $4 \mathrm{~B}$ class.

Table 6. $T$ test for Pre-test and Post-test $4 \mathrm{~B}$ class.

\begin{tabular}{|c|c|c|c|c|c|c|c|c|c|c|}
\hline \multicolumn{11}{|c|}{ Independent Samples test } \\
\hline & & \multirow[b]{2}{*}{$\mathrm{F}$} & \multirow[b]{2}{*}{ Sig. } & \multirow[b]{2}{*}{$t$} & \multirow[b]{2}{*}{ df } & \multirow{2}{*}{$\begin{array}{l}\text { Sig. (2- } \\
\text { tailed) }\end{array}$} & \multirow{2}{*}{$\begin{array}{c}\text { Mean } \\
\text { Differences }\end{array}$} & \multirow{2}{*}{$\begin{array}{l}\text { Std. Error } \\
\text { Differences }\end{array}$} & \multicolumn{2}{|c|}{$\begin{array}{l}95 \% \text { Confidence } \\
\text { Interval of } \\
\text { Difference }\end{array}$} \\
\hline & & & & & & & & & Lower & Upper \\
\hline hasil & $\begin{array}{l}\text { Equal variance } \\
\text { assumed }\end{array}$ & 4,989 & .033 & $\begin{array}{r}- \\
2,626\end{array}$ & 32 &, 013 & $-13,353$ & 5,085 & $-23,712$ & $-2,994$ \\
\hline & $\begin{array}{l}\text { Equal } \\
\text { variances not } \\
\text { assumed }\end{array}$ & & & 2,626 & 26,065 &, 014 & $-13,353$ & 5,085 & $-23,805$ & $-2,901$ \\
\hline
\end{tabular}

In table 6 , the Sig. 2 Tailed is 0.013 , so the pre-test and post-test scores of $4 \mathrm{~B}$ class have a significant difference. Because in this test, the initial and final abilities of the two classes are equally significantly different, it is necessary to carry out a normalized gain test to determine the percentage of effectiveness of hybrid learning and flipped classrooms.

\subsection{Effectivity Test}

\subsubsection{T-Test for gain score}

This test serves to analyze the increase in learning outcomes (gain value) between classes 4A and 4B whether the difference is significant

Table 7. T-test for 4A class and 4B class gain score.

\begin{tabular}{lllllllllll}
\multicolumn{10}{c}{ Independent Samples test } \\
\hline & F & Sig. & $\mathrm{t}$ & df & $\begin{array}{c}\text { Sig. (2- } \\
\text { tailed) }\end{array}$ & $\begin{array}{c}\text { Mean } \\
\text { Differences }\end{array}$ & $\begin{array}{c}\text { Std. Error } \\
\text { Differences }\end{array}$ & $\begin{array}{c}\text { 95\% Confidencerval of Difference } \\
\text { Lower }\end{array}$ & Upper \\
\hline $\begin{array}{l}\text { hasill Equal } \\
\text { variance } \\
\text { assumed }\end{array}$ & 952,336 & 1,288 & 34 &, 207 & 15,63672 & 12,14187 & $-9,03853$ & 40,31197 \\
$\begin{array}{l}\text { Equal } \\
\text { variances not } \\
\text { assumed }\end{array}$ & 1,263 & 28,402 &, 217 & 15,63672 & 12,37759 & $-9,70147$ & 40,97491 \\
\hline
\end{tabular}

In table 7, the Sig. 2 tailed t-test results, the gain value between $4 \mathrm{~A}$ class and $4 \mathrm{~B}$ class is 0.207 . This means that the value of Sig. 2 tailed above the level of significance. So, the difference between the gain value (the value of the increase in learning outcomes) 4A class and $4 \mathrm{~B}$ class is not significant. After knowing the significance of the difference in gain values for $4 \mathrm{~A}$ class and $4 \mathrm{~B}$ class, the next step is to find out the percentage and score to increase the ability of using hybrid learning and flipped classrooms.

\subsubsection{Normalized gain test}

According to Sundayana, to determine the value of increasing learning outcomes before and after treatment is given a normalized gain test (Sundayana, 2018). The gain test can be done if the data has different initial and final capabilities.

Table 8. Normalized gain test.

\begin{tabular}{|c|c|c|c|c|}
\hline \multicolumn{5}{|l|}{ Descriptives } \\
\hline & Class & & Statistic & Std. Error \\
\hline \multirow[t]{26}{*}{ gain_persen } & 4A Class & Mean & 49,5062 & 6,86725 \\
\hline & & $95 \%$ Confidences Interval forLower Bound & 35,0786 & \\
\hline & & Mean $\quad$ Upper Bound & 63,9337 & \\
\hline & & $5 \%$ Trimmed Mean & 49,8629 & \\
\hline & & Median & 45,8333 & \\
\hline & & Variance & 896,022 & \\
\hline & & Std. Deviation & 29,93363 & \\
\hline & & Minimum & $-7,41$ & \\
\hline & & Maximum & 100,00 & \\
\hline & & Range & 107,41 & \\
\hline & & Interquartile Range & 49,60 & \\
\hline & & Skewnes &, 164 &, 524 \\
\hline & & Kurtosis & -619 & 1,014 \\
\hline & 4B Class & Mean & 33,8695 & 10,29785 \\
\hline & & $95 \%$ Confidences Interval forLower Bound & 12,0390 & \\
\hline & & Mean $\quad$ Upper Bound & 55,6999 & \\
\hline & & $5 \%$ Trimmed Mean & 37,0596 & \\
\hline & & Median & 41,0714 & \\
\hline & & Variance & 1802,777 & \\
\hline & & Std. Deviation & 42,45912 & \\
\hline & & Minimum & $-78,57$ & \\
\hline & & Maximum & 88,89 & \\
\hline & & Range & 167,46 & \\
\hline & & Interquartile Range & 48,51 & \\
\hline & & Skewnes & $-1,223$ &, 550 \\
\hline & & Kurtosis & 861 & 1063 \\
\hline
\end{tabular}

Table 9. Tabulation of Normalized Gain Test Results.

\begin{tabular}{lllll}
\hline & Score & Presentation & Minimum Score & Maximum Score \\
\hline 4A class & 0.49 & $49.50 \%$ & -7.41 & 100 \\
4B class & 0.34 & $33.86 \%$ & -78.57 & 88.89 \\
\hline
\end{tabular}

In order to know the gain score interpretation, it presented by following table (Sundayana 2018).

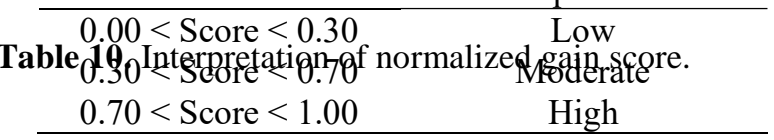

From the normalized gain test results on the pre-test and post-test values for $4 \mathrm{~A}$ class and $4 \mathrm{~B}$ class, the gain score for $4 \mathrm{~A}$ class using hybrid learning is 0.49 , while for $4 \mathrm{~B}$ class with the application of flipped classroom, the gain value is 0.34 so that both have relatively moderate effectiveness as well. To compare the effectiveness between hybrid learning and flipped classroom, we can see the percentage gain. The percentage gain in hybrid learning in the $4 \mathrm{~A}$ class is $49.50 \%$, while the flipped classroom in the 4B class has a gain percentage of $33.86 \%$, meaning that even though they do not have a significant difference in improving learning outcomes, the percentage effectiveness of hybrid learning is greater than flipped classrooms. So hybrid learning has a higher effectiveness than flipped classrooms in improving learning outcomes in the 
chuukyuu bunpou course in 4th semester student of Japanese Education of Muhammadiyah University Prof. DR. HAMKA 2019-2020.

\section{CONCLUSION}

Before treatment using hybrid learning and flipped classroom in the blended learning, the pre-test scores for 4A class and 4B class were on average below 70 . However, after treatment using hybrid learning and flipped classrooms, both $4 \mathrm{~A}$ class and $4 \mathrm{~B}$ class experienced an increase in learning outcomes, for $4 \mathrm{~A}$ class using hybrid learning is $49.5 \%$ while the $4 \mathrm{~B}$ class using flipped classroom is around $33 \%$. This means that the use of hybrid learning and flipped classroom is equally effective in improving learning outcomes in the chuukyuu bunpou course. however, the percentage of effectiveness of hybrid learning is higher, even closer to the level of effectiveness than flipped classrooms. So it can be concluded that in blended learning, hybrid learning and flipped classrooms even though they have the same level of effectiveness, hybrid learning is more effective because the percentage of effectiveness is higher in improving learning outcomes than flipped classrooms in the chuukyuu bunpou course in the fourth semester students of UHAMKA Japanese Language Education 2019-2020.

\section{AUTHORS' CONTRIBUTIONS}

Rita Agustina is wrote the paper as the main author, contributed research ideas, and performed the analysis. And Aulia Istianingrum is wrote the paper as the second author, collected the data, and performed the analysis.

\section{ACKNOWLEDGMENTS}

We thank Mr. Dr. Desvian Bandarsyah, M.Pd (Dean of the Faculty of Teacher Training and Education of University Muhammadiyah Prof. DR. HAMKA) for the support; we also thank Mr. Dedi Suryadi, P.hd (Deputy dean of the faculty of Language and Literature of Muhammadiyah University of Yogyakarta).

\section{REFERENCES}

[1] Alnajdi, S. (2014). HYBRID LEARNING IN HIGHER EDUCATION.

[2] Arifin, Syamsul (2020). Design Kurikulum Pendidikan Tinggi Sesuai dengan KKNI \& SN Dikti dengan Pendekatan OBE di Era Industri 4.0. Tehnik Fisika ITS: Surabaya

[3] Bryan, A., \& Volchenkova, K. N. (2016). Blended Learning: Definition, Models, Implications for Higher Education. Bulletin of the South Ural State University Series "Education. Education Sciences," 8(2), 24-30. https://doi.org/10.14529/ped160204
[4] Cuaca Dharma, H. R., Asmarani, D., \& Dewi, U. P. (2017). Basic Japanese Grammar and Conversation e-learning through Skype and Zoom Online Application. Procedia Computer Science, 116, 267-273.

https://doi.org/10.1016/j.procs.2017.10.055

[5] Ismail, S. S., \& Abdulla, S. A. (2019). Virtual flipped classroom: New teaching model to grant the learners knowledge and motivation. Journal of Technology and Science Education, 9(2), 168-183. https://doi.org/10.3926/jotse.478

[6] Jusuf, H., Ibrahim, N., \& Suparman, A. (2019). Developing a hybrid learning strategy for students' engagement in object-oriented programming course. Universal Journal of Educational Research, $7(9 \quad$ A), $\quad 78-87$. https://doi.org/10.13189/ujer.2019.071610

[7] Milman, N. (2012). The flipped classroom strategy: What is it and how can it best be used? Distance Learning, 9, 85-87.

[8] Narayana, I. W. G. (2016). Analisis Terhadap Hasil Penggunaan Metode Pembelajaran Synchronous Dan Asynchronous. Seminar Nasional Teknologi Informasi Dan Multimedia 2016 STMK AMIKOM Yogyakarta 6-7 Februari 2016, 6-7.

[9] Pavanelli, R. (2018). The Flipped Classroom: A Mixed Methods Study of Academic Performance and Student Perception in EAP Writing Context 4205 Bonaventure Blvd. 5(2), 16-26. https://doi.org/10.30845/ijll.v5n2p3

[10] Rindaningsih, I. (2018). Efektifitas Model Flipped Classroom dalam Mata Kuliah Perencanaan Pembelajaran Prodi S1 PGMI UMSIDA. Proceedings of the ICECRS, 1(3), 51-60. https://doi.org/10.21070/picecrs.v1i3.1380

[11] Sojayapan, C., \& Khlaisang, J. (2018). The effect of a flipped classroom with online group investigation on students' team learning ability. Kasetsart Journal of Social Sciences, 4-9. https://doi.org/10.1016/j.kjss.2018.02.003

[12] Sundayana, R. (2018). Statistika Penelitian Pendidikan. Bandung: Penerbit Alfabeta.

[13] Uwes Anis Chaeruman, (2020). Flipped Learning. Tips Implementasinya dalam masa dan pasca Pandemi Covid 19. Tehnologi Pendidikan UNJ

[14] Teo, P. (2019). Teaching for the 21st century: A case for dialogic pedagogy. Learning, Culture and Social Interaction, 21(January), 170-178. https://doi.org/10.1016/j.lcsi.2019.03.009 